\title{
Aktivitas Anti Jamur Ekstrak Purifikasi Daun Galing (Cayratia trifolia L. Domin) Terhadap Jamur Candida albicans
}

\author{
Asriullah Jabbar, ${ }^{* 1}$, Muhammad Ilyas Yusuf ${ }^{1,2}, \operatorname{Irman}^{3}$, Asri Yuli ${ }^{4}$ \\ ${ }^{1}$ Fakultas Farmasi Universitas Halu Oleo, Kampus Hijau Bumi Tridharma Anduonohu Kendari 93232 \\ ${ }^{2}$ Akademi Analis Kesehatan Bina Husada Kendari, Jl. Sorumba no. 17 Kendari, 93117 \\ ${ }^{3}$ Dinas Kesehatan Kabupaten Buton Utara, Provinsi Sulawesi Tenggara, Buranga 93673, \\ ${ }^{4}$ Akademi Farmasi Bina Husada Kendari, Jl. Sorumba No.17 Kendari, 93117
}

\begin{abstract}
Abstrak
Galing (Cayratia trifolia L.Domin) merupakan tumbuhan yang sering digunakan sebagai obat keputihan, kandungan dari tumbuhan ini adalah asam hidrisinat, delphinidin, flavonoid, alkaloid, fitosterol, saponin dan tanin. Tujuan penelitian ini adalah untuk mengetahui aktivitas antijamur dari purifikasi ekstrak daun galing terhadap Candida albicans dan untuk mengetahui konsentrasi efektif ekstrak terpurifikasi daun galing sebagai antijamur C. albicans. Jenis penelitian yang digunakan adalah eksperimental, dengan desain RAL (Rancangan Acak Lengkap). Ekstrak terpurifikasi daun galing dibuat dengan konsentrasi 10\%, 20\%, 30\%, kemudian ini dilakukan pengujian antijamur dengan metode cylinder cup. Hasil penelitian menunjukkan bahwa ekstrak terpurifikasi daun galing memiliki aktivitas antijamur yakni konsentrasi $10 \%$ memiliki rata - rata zona hambat $9 \mathrm{~mm}$, konsentrasi $20 \%$ memiliki rata-rata zona hambat $11 \mathrm{~mm}$, konsentrasi 30\% memiliki rata-rata zona hambat 15,6 mm. Berdasarkam uji statistik ANOVA, terlihat bahwa $F_{\text {hitung }}(98,2)>\mathrm{F}_{\text {tabel }}(3,48)$ yang berarti perlakuan yang diuji memberikan hasil yang signifikan terhadap pertumbuhan jamur C. albicans. Untuk uji lanjut BNT menunjukkan hasil konsentrasi $30 \%$ memiliki aktivitas antijamur $C$. albicans paling efektif .
\end{abstract}

Kata kunci: antijamur, Candida albicans, daun galing, purifikasi, zona hambat

\section{Pendahuluan}

Candida albicans adalah fungi oportunistik pathogen yang dapat menyebabkan berbagai penakit pada manusia seperti sariawan, lesi pada kulit, dan vulvoaginitis [1]. Obat-obat sintetik antifungi sebagai agen pengobatan infeksi jamur pada waktu ini telah dikembangkan secara luas. Namun, penggunaan obatobat antifungi yang terbuat dari bahan kimia, sering menimbulkan banyak masalah seperti adanya efek samping yang serius, resistensi, aturan pakai yang menyulitkan, dan perlunya pengawasan dokter, berkaitan dengan masalah di atas, perlu dicari agen lain yang mempunyai daya antifungi lebih efektif dan murah $[2,3]$.

Hingga saat ini obat herbal telah diterima secara luas hampir di seluruh dunia. Faktor pendorong meningkatnya penggunaan obat herbal di negara maju adalah usia harapan hidup yang lebih panjang pada saat prevalensi penyakit kronik meningkat, adanya kegagalan pada saat penggunaan obat modern untuk penyakit

\footnotetext{
* KBK Farmakologi dan Farmasi Klinik, Fakultas Farmasi UHO
} Email: asriullah.jabbar@gmail.com tertentu serta semakin luasnya akses informasi mengenai obat herbal di seluruh dunia [4].

Tumbuhan galing merupakan salah satu tanaman obat yang secara empiris digunakan untuk keputihan [5]. Kandungan dari tumbuhan galing yaitu alkaloid, fitosterol, saponin, dan tanin [6]. Berdasarkan penelitian sebelumnya senyawa alkaloid, tanin dan saponin dapat menghambat pertumbuhan jamur $C$. albicans dengan cara yang berbeda-beda [7].

\section{Metode}

\subsection{Umum}

Jenis penelitian yang digunakan adalah penelitian eksperimen, dengan desain penelitian RAL (rancangan Acak Lengkap). Sampel daun galing diperoleh dari wilayah Kelurahan Lepo-lepo Kecamatan Baruga Kota 
Kendari. Jamur C. albicans diperoleh dari Laboratorium Kesehatan Provinsi Sulawesi Tenggara, Kendari.

\subsection{Pembuatan Ekstrak Terpurifikasi}

Daun galing yang telah diambil dicuci bersih, dirajang, dikeringkan dan diekstraksi menggunakan etanol 96\%. Ekstrak yang diperoleh dikentalkan menggunakan rotavapor, selanjutnya dipurifikasi dengan menambahkan pelarut $n$-heksana sebanyak 200 $\mathrm{mL}$ setelah itu digojog selama 5 menit dan didiamkan hingga terbentuk dua lapisan. Lapisan $n$-heksana dipisahkan, dan dilakukan pengulangan purifikasi ekstrak sampai fase $n$-heksana berwarna bening. Fase etanol yang diperoleh selanjutnya dipekatkan dengan waterbath.

\subsection{Pembuatan Sampel Uji}

Ditimbang ektrak terpurifikasi daun galing konsentrasi 10\% 0,5 gram, konsentrasi 20\% 1 gram, konsentrasi 30\% 1,5 gram, lalu masukkan dalam labu tentu ukur $5 \mathrm{~mL}$, cukupkan volumenya dengan aqua pro injeksi hingga tanda batas. Pembuatan kontrol positif, digerus halus nystatin, ditimbang 1 gram, cukupkan volumenya hingga $9 \mathrm{~mL}$ dengan Api, homogenkan.

\subsection{Pengujian Diameter Zona Hambat}

Pengujian diameter zona hambat menggunakan metode cylinder cup. Media PDA dipipet sebanyak 20 $\mathrm{mL}$. Suspensi jamur ke digoreskan di permukaan media PDA yang telah memadat. Cylinder cup diletakkan pada permukaan media yang telah memadat, dimasukkan ekstrak terpurifikasi daun galing dan kontrol kedalam Cylinder cup sebanyak 8 tetes, lalu diinkubasi pada suhu $37^{\circ} \mathrm{C}$ selama $3 \times 24$ jam.

\subsection{Analisis Data}

Pengolahan data yang digunakan dalam penelitian ini adalah uji ANOVA dilanjutkan uji BNT pada tingkat kepercayaan $95 \%(\propto=0,05)$ dengan menggunakan SPSS 18.

\section{Hasil dan Pembahasan}

Penelitian yang telah dilakukan memperlihatkan bahwa rata-rata dari beberapa konsentrasi dengan kontrol serta blanko memiliki perbedaan. Untuk konsentrasi $10 \%$ memiliki rata-rata $9 \mathrm{~mm}$, pada konsentrasi $20 \%$ memiliki rata-rata $11 \mathrm{~mm}$ dan konsentrasi $30 \%$ memiliki rata-rata $15.6 \mathrm{~mm}$, sedangkan kontrol memiliki rata-rata $21.3 \mathrm{~mm}$ dan aquadest sebagai blanko tidak memiliki zona hambat. Berdasarkan klasifikasi respon hambatan pertumbuhan mikroba semua konsentrasi memiliki daya hambat kuat (8)

Tabel 1. Hasil uji aktivitas antijamur daun galing (Cayratia trifolia L.Domin) terhadap jamur Candida albican.

\begin{tabular}{cccccc}
\hline \multirow{2}{*}{ Sampel } & \multicolumn{3}{c}{$\begin{array}{c}\text { Diameter zona hambat } \\
(\mathrm{mm})\end{array}$} & $\begin{array}{c}\text { Total } \\
(\mathrm{mm})\end{array}$ & $\begin{array}{c}\text { Rata- } \\
\text { rata } \\
(\mathrm{mm})\end{array}$ \\
\cline { 2 - 4 } & I & II & III & & 9 \\
\hline Konsentrasi $10 \%$ & 9 & 8 & 10 & 27 & 9 \\
\hline Konsentrasi $20 \%$ & 13 & 9 & 11 & 33 & 11 \\
\hline Konsentrasi 30\% & 16 & 14 & 17 & 47 & 15.6 \\
\hline Nystatin & 21 & 23 & 20 & 64 & 21.3 \\
\hline Akuades & 0 & 0 & 0 & 0 & 0 \\
\hline
\end{tabular}

Terdapat perbedaan rata-rata antara replikasi I, II, dan III, dimana konsentrasi $10 \%$ memiliki rata-rata terendah dan $30 \%$ memiliki rata-rata yang optimal dari ketiga konsentrasi. Dapat dikatakan bahwa ekstrak terpurifikasi daun galing mempunyai aktivitas terhadap pertumbuhan jamur Candida albicans, serta berdasarkan dilihat dari F hitung yang lebih besar $(98,2)$ di bandingkan dengan $\mathrm{F}$ tabel $(3,48)$. Maka daya hambat ekstrak terpurifikasi daun galing terhadap jamur C. albicans terdapat perbedaan nyata.

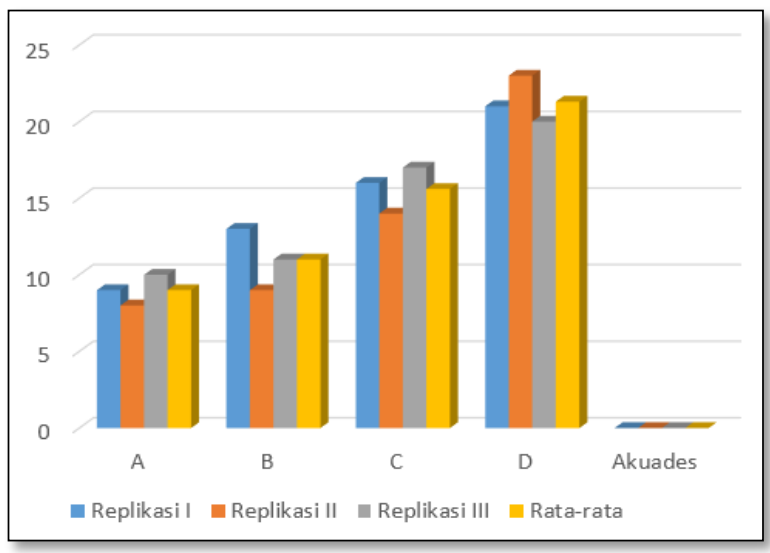

Gambar 1. Diagram hasil zona hambat ekstrak terpurifikasi daun galing terhadap C. albicans

Berdasarkan tabel uji anova F hitung $(98,2)>\mathrm{F}$ tabel $(3,48)$, yang berarti perlakuan yang diuji memberikan hasil yang signifikan terhadap pertumbuhan jamur Candida albicans. Tumbuhan galing mengandung senyawa alkaloid, saponin, dan tanin (6), Menurut penelitian sebelumnya Senyawa ini dapat menghambat pertumbuhan jamur Candida albicans (7). Alkaloid menghambat respirasi sel jamur, senyawa saponin dapat menganggu stabilitas sel pada jamur yang mengakibatkan kerusakan tanin sel dan menyebabkan 
keluarnya berbagai komponen penting dari dalam sel jamur yaitu protein, asam nukleat dan nukleotida, dan tanin merupakan senyawa yang bersifat lipofilik sehingga mudah terkait pada dinding sel dan mengakibatkan kerusakan dinding sel jamur [9].

Untuk menunjukkan perlakuan mana yang memberikan efek paling besar dari uji aktivitas ekstrak terpurifikasi daun galing terhadap pertumbuhan jamur Candida albicans, maka perlu dilanjutkan dengan uji Beda Nyata Terkecil (BNT) dengan hasil konsentrasi $30 \%$ memiliki aktivitas antijamur $C$. albicans paling efektif tetapi berbeda dengan kontrol positif.

\section{4. . Kesimpulan}

Ekstrak terpurifikasi daun galing memiliki aktivitas terhadap pertumbuhan jamur Candida albicans. Dari ketiga perlakuan yang paling efektif sebagai antijamur Candida albicans adalah konsentrasi $30 \%$, tetapi berbeda dengan kontrol positif

\section{Daftar Pustaka}

1. Sjam KR. Kolonisasi Candida dalam Rongga Mulut, Majalah Kedokteran FK UKI, 2012, XXVIII(1);39-41.

2. Saifuddin A, Rahayu V, Teruna HY. Standarisasi Bahan Obat Alam, Yogyakarta: Graha Ilmu, 2011.
3. Rintiswati N, Winarsih NE, Malueka, RG. Potensi Antikandida Ekstrak Madu secara In Vitro dan In Vivo. Berkala Ilmu Kedokteran, 2004, 36(4);187-94.

4. Katno, Widyastuti Y, Prapti IY, Rahmawati N, Mujahid R. Tingkat Manfaat Keamanan dan Efektifitas Tanaman Obatdan obat Tradisional, Tawangmangu: Balai Besar Penelitian dan Pengembangan Tanaman Obat dan Obat Tradisional Badan Penelitian dan Pengembangan Kesehatan RI, 2008.

5. Kumar D, Gupta J, Kumar, S, Arya R, Kumar T, Gupta A. A review on chemical and biological properties of Cayratiatrifolia Linn (Vitaceae), Pharmacogn Rev., 2011, 5(10);184-8. doi: 10.4103/0973-7847.91117.

6. Agriningsi W. Identifikasi kandungan metabolit sekunder ekstrak etanol herba tumbuhan galing (Cayratiatrifolia L.Domin)". Karya Tulis Ilmiah, Amd. Farm, Kendari: Akademi Farmasi Bina Husada. 2016.

7. Fitriani A, Aryani A, Yusuf H, Permatasari Y. The Exploration of Ketosynthase Gene on Endophytic Bacterial Root of Vetiveria zizanioides L., IJBAS-IJENS, 2012, 13(04);112-119.

8. Pan X, Chen F, Wua T, Tang H, Zhao Z. The acid, bile tolerance and antimicrobial property of Lactobacillus acidophilus NIT, Food Control, 2009, 20(6);598-602.

9. Alifah RR, Khotimah S, Turnip M. Efektivitas ekstrak Methanol Daun Sembung Rambat (Mikania micrantha Kunth) terhadap pertumbuhan jamur Candida albicans. Jurnal Protobiont, 2012, 4(1); 52-57. 